Check for updates

Cite this: RSC Adv., 2019, 9, 12097

Received 10th October 2018

Accepted 19th March 2019

DOI: $10.1039 / \mathrm{c} 8 \mathrm{ra} 08380 \mathrm{k}$

rsc.li/rsc-advances

\section{Pinostrobin inhibits proliferation and induces apoptosis in cancer stem-like cells through a reactive oxygen species-dependent mechanism $\uparrow$}

\begin{abstract}
Alka Jadaun, $\$$ Sapna Sharma, $\$$ Radha Verma and Aparna Dixit (D)*
Current treatments and targeted therapies for malignancies are limited due to their severe toxicity and the development of resistance against such treatments, which leads to relapse. Past evidence has indicated that a number of plant-derived dietary agents possess biological activity against highly tumorigenic and resistant cell populations associated with cancer relapse. These subpopulations, termed cancer stem-like cells (CSCs), have been targeted with plant-derived dietary flavonoids. The present study was undertaken to assess the anti-proliferative potential of pinostrobin, a dietary flavonoid, against CSCs. Sphere-forming cells were developed from HeLa cell lines using specific culture conditions. The existence of a CSC population was confirmed by the morphological examination and analysis of surface markers using confocal microscopy and flow cytometry. The effect of pinostrobin on the cell viability of the CSC population, evaluated through MTT reduction assays and the expression levels of surface markers $\left(\mathrm{CD} 44^{+}\right.$and $\left.\mathrm{CD} 24^{+}\right)$, was studied through various biological assays. HeLa-derived CSCs showed higher $\mathrm{CD}_{4} 4^{+}$and lower $\mathrm{CD} 24^{+}$expression. Pinostrobin inhibited the self-renewal capacity and sphere formation efficiency of CSCs in a dose-dependent manner. Increased ROS production, and decreased mitochondrial membrane potential and $\mathrm{CD}_{4} 4^{+}$expression indicated that pinostrobin promoted ROSmediated apoptosis in CSCs. These results thus demonstrate the therapeutic potential and effectiveness of pinostrobin in the chemoprevention and relapse of cancer by targeting the CSC population. Thus, pinostrobin, in combination with currently available chemo and radiation therapies, could possibly be used as a safe strategy to alleviate adverse treatment effects, together with enhancing the efficacy.
\end{abstract}

\section{Introduction}

In India, the prevalence of cervical cancer is the highest among all the cancer cases in females. It is the most common cancer among 15-44 aged females. ${ }^{1}$ Compared to the urban population, the rural population is at a higher risk of developing cervical cancer. Despite great advances in targeted therapies and major steps toward customised therapy for cancer patients, there has yet not been a significant increase in survival rate for many individuals. Target cancer therapies show limited efficacy, due to the specific criteria of individuals. It has been observed in many patient cohorts that drug efficacy imbalance often arises due to the development of drug resistance through acquiring genetic and epigenetic alterations. ${ }^{2}$ Survival rates can be increased, if the disease is diagnosed at an early stage, with improved treatment strategies.

Gene Regulation Laboratory, School of Biotechnology, Jawaharlal Nehru University, New Delhi-110067, India.E-mail: adixit7@gmail.com; adix2100@mail.jnu.ac.in $\dagger$ Electronic supplementary information (ESI) available. See DOI: 10.1039/c8ra08380k

$\ddagger$ Equal contribution.
Despite the availability of several therapies, a number of patients develop drug resistance and face tumour relapse, significantly contributing to a poor survival rate. ${ }^{3}$ It is now well established that cancer relapse and progression is influenced by a cell population within the cancerous tissue, termed as cancer stem-like cells or cancer stem cells (CSCs). ${ }^{\mathbf{4}-6}$ These CSCs play a major role in determining tumor aggressiveness, heterogeneity, drug resistance and recurrence of the disease. ${ }^{5,7,8}$ Generally, conventional and targeted therapy target only mature, proliferating tumor cells without affecting the CSC population. ${ }^{\mathbf{9}, 10}$ Targeting the CSC population would possibly help in controlling disease progression and thus enhance the survival rate of cancer patients. If treatment results in the elimination of CSCs, it helps to reduce tumor growth and prevent relapse. Since CSCs adapt to different survival mechanisms, it is important to identify a molecule that could simultaneously modulate a number of cellular pathways/mechanisms.

Natural products such as curcumin, berberine and resveratrol have been reported to interact with a number of cellular molecules, controlling the proliferation of the CSC population. ${ }^{\mathbf{1 1}}$ These natural products play a crucial role in targeting the CSC population and its surface markers, and modulate critical signalling pathways that are essential for its 
maintenance and survival. ${ }^{12,13}$ Pinostrobin $\left(\mathrm{P}_{\mathrm{N}}\right)$, extracted from several medicinal plants, belongs to the flavanone family of phytochemicals. The anti-leukemic and anti-cancer activities of $\mathrm{P}_{\mathrm{N}}$ against different types of carcinomas have been reported. ${ }^{\mathbf{1 3 - 1 5}}$ We have previously reported the cytotoxic activity of $\mathrm{P}_{\mathrm{N}}$ in cervical cancer cells, without any cytotoxic effects on normal HEK293 cells, and demonstrated that it induced ROS-mediated cell death. ${ }^{16}$ In addition, we also demonstrated the direct interaction of $\mathrm{P}_{\mathrm{N}}$ with topoisomerase $\mathrm{I}$, an enzyme involved in DNA replication, and inhibited its activity. ${ }^{17} \mathrm{P}_{\mathrm{N}}$ from different sources has been reported to regulate a variety of cellular systems that are necessary for normal cellular function, ${ }^{\mathbf{1 8}}$ by possibly affecting multiple cellular and molecular processes. Since it has shown anti-proliferative activity in cancer cells, it is hypothesized that it may have the potential to inhibit the proliferation of CSCs and induce cell death. In this study, we investigated if $\mathrm{P}_{\mathrm{N}}$ is indeed able to target a HeLa-CSC population and affect their proliferation. We further investigated the possible mechanism underlying $\mathrm{P}_{\mathrm{N}}$-induced cell death in HeLa-CSCs.

\section{Materials and methods}

\section{Reagents}

Analytical grade chemicals were used in the present study. Pinostrobin $\left(\mathrm{P}_{\mathrm{N}}\right)$, doxorubicin $\left(\mathrm{D}_{\mathrm{X}}\right), N$-acetyl cysteine (NAC) and fluorescent dyes used in the study such as 5,5',6,6'-tetrachloro1,1',3,3'-tetraethylbenzimidazolyl-carbocyanine iodide (JC-1), $2^{\prime}, 7^{\prime}$-dichlorofluorescin diacetate (DCFH-DA), hydroethidine (HE), Annexin V-FITC, propidium iodide (PI), verapamil, Hoechst 33342 dye and 10- $N$-nonyl acridine orange (NAO) were purchased from Sigma-Aldrich Chemical Co., USA. Epidermal growth factor and basic fibroblast growth factor (bFGF) were obtained from Invitrogen, USA. All buffers/solutions used in the study were prepared in Milli-Q water. $\mathrm{P}_{\mathrm{N}}$ stock solution $(20 \mathrm{mM})$ was prepared in triple solvent (TS, dimethyl formamide : acetonitrile : dimethyl sulfoxide, $1: 1: 1){ }^{19}$ Triple solvent was used as a vehicle control (VC). We included $D_{\mathrm{X}}$ as a reference control in all of the experiments as it has been shown to inhibit the cell proliferation of CSCs derived from human colon carcinoma HT29 cells ${ }^{20}$ and ovarian carcinoma SKOV3 cells. ${ }^{21}$

\section{Cell culture}

HeLa cells (human cervical cancer cell line) were obtained from the National Centre for Cell Science (NCCS), Pune (India), cultured and maintained in Dulbecco's modified Eagle's medium (DMEM) supplemented with 10\% foetal bovine serum (FBS), $100 \mathrm{U} \mathrm{ml}^{-1}$ of penicillin and $100 \mu \mathrm{g} \mathrm{ml} \mathrm{m}^{-1}$ of streptomycin (Biological Industries, Israel) at $37{ }^{\circ} \mathrm{C}$ in a $5 \% \mathrm{CO}_{2}$ incubator with a 95\% air atmosphere, essentially as described previously. ${ }^{16}$

\section{Identification of the side population}

Sphere forming cells (SFCs) were also recognised as the side population (SP).$^{19}$ For identification and validation of the SP in the parent HeLa cell population, Hoechst 33342 staining in the presence or absence of verapamil, a calcium channel antagonist, was performed. The adherent parent HeLa cells were trypsinised $(0.25 \%)$ and washed twice with $1 \times$ PBS. The cells $(1$ $\times 10^{4} /$ well) were incubated in pre-warmed DMEM (containing $2 \%$ fetal bovine serum (FBS), $1 \mathrm{mM}$ HEPES, and $5 \mu \mathrm{g} \mathrm{m}{ }^{-1}$ Hoechst 33342) for $90 \mathrm{~min}$ at $37{ }^{\circ} \mathrm{C}$ in the dark on a rocking platform shaker with slow agitation. The CSCs $\left(1 \times 10^{4}\right.$ cells per well) were generated as described above and cultured in SFM. To obtain appropriate sized spheres, $100 \mu \mathrm{l}$ of fresh SFM was added after every $48 \mathrm{~h}$ for 8 days. The cells were washed twice with pre-cooled $1 \times$ PBS and centrifuged at $2000 \mathrm{rpm}$ at $4{ }^{\circ} \mathrm{C}$. The cells were then incubated with verapamil $(50 \mu \mathrm{M})$ at $37{ }^{\circ} \mathrm{C}$ for 30 min after the addition of Hoechst 33342 stain, to check if the fluorescent efflux from the SP cells present in the HeLa population was blocked by verapamil. The cells were counterstained with propidium iodide (PI) $\left(2 \mathrm{mg} \mathrm{ml}^{-1}\right)$ in the dark. Acquisition was performed using a FACS Calibur ${ }^{\mathrm{TM}}$ (Beckon Dickinson Immuno cytometry system, San Jose, USA) operated in dual wavelength mode, by measuring the fluorescence of the Hoechst 33342 dye and PI at 460 and $580 \mathrm{~nm}$, respectively. The results were analysed by FCS Express.v5 Flow Cytometry data analysis software. A small number of cells that were capable to efflux Hoechst stain with low fluorescing were identified as the SP.

\section{In vitro culture and passage of sphere forming cells}

SFCs were generated from HeLa cells using the method developed by López et al. ${ }^{22}$ HeLa cells $\left(1 \times 10^{6}\right.$ cells per $\left.\mathrm{ml}\right)$ were cultured in $2 \mathrm{ml}$ of serum-free media (SFM) supplemented with epidermal growth factor (EGF) and basic fibroblast growth factor (bFGF), (20 ng ml $\mathrm{ml}^{-1}$ each) and bovine serum albumin (BSA) $(0.4 \%)$ in a $35 \mathrm{~mm}$ culture dish at $37{ }^{\circ} \mathrm{C}$ in a $5 \% \mathrm{CO}_{2}$ atmosphere. The culture medium was replenished every $48 \mathrm{~h}$ after SFC generation for the next 8 days. After generation of 70$80 \%$ spheres, the SFCs were collected by gentle centrifugation (2500 rpm, $5 \mathrm{~min}$ ). Each sphere was separated using $500 \mu \mathrm{l}$ of EDTA (1.0 mM) and collected using a Pasteur pipette followed by gentle shaking at $2500 \mathrm{rpm}$ for $5 \mathrm{~min}$ to achieve single-cell suspension. These SFCs were recognized as cancer stem-like cells (CSCs). ${ }^{23}$

\section{Morphological assessment of CSCs}

The growth of the cells was monitored on days 1, 3, 6, 9, and 12 . On day 12 , the spheres were detached from the surface of the flask and floated in suspension as clumps/aggregates. The CSCs bodies thus collected, were visualized under a bright field microscope (Leica, DMIL, Germany), as described by Gu et al. ${ }^{19}$ Parent HeLa cells $\left(1 \times 10^{4}\right.$ cells per well $)$, included as a control, were cultured in complete DMEM at $37{ }^{\circ} \mathrm{C}$ in a $5 \% \mathrm{CO}_{2}$ incubator.

\section{Identification of the CSC population}

Confocal microscopy. The CSC population was confirmed by analysis of the expression of the surface markers CD $24^{+} / \mathrm{CD} 44^{+}$, as described by Gu et al. ${ }^{19}$ CSCs and parent HeLa cells were 
cultured on a cover slip $\left(1 \times 10^{4}\right.$ cells per coverslip) and incubated for $24 \mathrm{~h}$ in SFM and constituted DMEM, respectively. The cells were subjected to $\mathrm{P}_{\mathrm{N}}(50$ and $100 \mu \mathrm{M})$ and $\mathrm{D}_{\mathrm{X}}(10 \mu \mathrm{M})$ for $48 \mathrm{~h}$. Cells were fixed with $2 \%$ paraformaldehyde for $20 \mathrm{~min}$ at room temperature (RT), washed twice with $1 \times$ PBS and stained with FITC (fluorescein isothiocyanate)-conjugated anti-CD44 and R-phycoerythrin (PE)-conjugated anti-CD24 antibodies $(1: 100)$ (Invitrogen, USA) for $30 \mathrm{~min}$ at RT. The cells were then washed once with $1 \times$ PBS and the morphology of the stained CSCs and parent HeLa cells was examined under an Olympus Fluoview FV1000 confocal laser-scanning microscope at $40 \times$ magnification using a 1.4NA oil objective lens at the Advanced Instrument Research Facility (AIRF), JNU, New Delhi (India). The size of the acquired images was $512 \times 512$ pixels $(0.414 \mu \mathrm{m}$ per pixel).

\section{Quantification of the $\mathrm{CD}^{+} 4^{+} / \mathrm{CD}^{+} 4^{+}$expression levels}

Changes in the expression levels of $\mathrm{CD} 24^{+} / \mathrm{CD} 44^{+}$in the CSC population and HeLa cells induced by different treatments, i.e. $\mathrm{P}_{\mathrm{N}}, \mathrm{D}_{\mathrm{X}}$, vehicle and in the untreated CSCs population, were quantified using a FACS Calibur ${ }^{\mathrm{TM}}$ at $488 \mathrm{~nm}$ (ex). The green and red fluorescence intensities were visualized in the FL1 and FL2 channels, respectively and analysed using FCS Express.v5 Flow Cytometry data analysis software.

\section{Regeneration of the parent HeLa cells from the CSCs}

Regeneration of the parent HeLa cells from the CSCs was carried out using the method of $\mathrm{Gu}$ et al. with minor modifications. ${ }^{19} \mathrm{CSCs}\left(1 \times 10^{4}\right.$ cells per well $)$ were cultured in constituted DMEM in a $35 \mathrm{~mm}$ culture dish at $37{ }^{\circ} \mathrm{C}$ in a humidified $5 \% \mathrm{CO}_{2}$ incubator for 12 days and the morphology of the generated HeLa cells was assessed under a bright field microscope (Leica, DMIL, Germany).

\section{Cell proliferation assay}

CSCs were cultured $\left(1 \times 10^{4}\right.$ cell per well) in SFM, (as described above). Cells were seeded separately in 96 well plates and cultured at $37{ }^{\circ} \mathrm{C}$ in a $5 \% \mathrm{CO}_{2}$ incubator. The cytotoxic effect of $\mathrm{P}_{\mathrm{N}}$ on the CSCs was evaluated by 3-(4,5-dimethylthiazol-2-yl)2,5-diphenyl tetrazolium bromide (MTT) reduction assay. ${ }^{21}$ CSCs were treated with different concentrations of $\mathrm{P}_{\mathrm{N}}$ and $\mathrm{D}_{\mathrm{X}}$, as indicated in the legends to the figures, and corresponding volume of vehicle as a control for 24 and $48 \mathrm{~h}$. MTT assay was also performed in the $\mathrm{P}_{\mathrm{N}}$-treated cells in the presence or absence of $5 \mathrm{mM}$ NAC, an ROS-scavenger. ${ }^{24}$ After treatment, MTT ( $0.5 \mathrm{mg} \mathrm{ml}^{-1}$ ) was added to each well and incubated for the next $4 \mathrm{~h}$ in the dark at $37^{\circ} \mathrm{C}$ in a $\mathrm{CO}_{2}$ incubator. The medium was removed and formazan crystals were dissolved in $100 \mu \mathrm{l}$ of dimethyl sulfoxide (DMSO) with gentle shaking. The amount of formazan crystals was measured at $570 \mathrm{~nm}$ using a TECAN ELISA reader (Tecan Sunrise ${ }^{\mathrm{TM}}$ ). The data are expressed as cytotoxicity (\%) with respect to vehicle treated cells.

\section{Sphere-forming efficiency (SFE) assay}

The effect of $\mathrm{P}_{\mathrm{N}}(50$ and $100 \mu \mathrm{M})$ on the sphere forming efficiency (SFE) of sphere forming cells was investigated. Subconfluent sphere forming cells $\left(1 \times 10^{4}\right.$ cells per well $)$ were dissociated using $1 \times$ EDTA $(1.0 \mathrm{mM})$ to achieve a single cell suspension. Cells $\left(1 \times 10^{4}\right.$ cells per well $)$ were seeded in a 6 -well culture dish and cultured in SFM with the addition of $25 \mu \mathrm{l}$ per well of fresh SFM after every $48 \mathrm{~h}$. The numbers of spheres generated in each well were examined under a bright field microscope, as described by López et al. ${ }^{22}$

\section{Flow cytometric analysis}

Determination of ROS production. The effect of $\mathrm{P}_{\mathrm{N}}$ treatment on intracellular ROS production in CSCs was determined using fluorescent probes. The CSCs $\left(1 \times 10^{4}\right.$ cells per well $)$ treated with $\mathrm{P}_{\mathrm{N}}$ in the presence or absence of NAC, or $\mathrm{D}_{\mathrm{X}}$ for $48 \mathrm{~h}$, were stained with fluorescent probes, DCFH-DA $(5.0 \mu \mathrm{M}),{ }^{25}$ NAO (1 $\mu \mathrm{M})^{26}$ and $\mathrm{HE}(2.5 \mu \mathrm{M})^{27}$ in Hank's balanced salt solution (HBSS). Cells were incubated with different probes for $30 \mathrm{~min}$ in the dark at $37{ }^{\circ} \mathrm{C}$, washed with $1 \times$ PBS and resuspended in HBSS for data acquisition. Fluorescence was measured using a FACS Calibur ${ }^{\mathrm{TM}}$ with default settings. The green and red fluorescence intensities were acquired using the FL1 and FL2 channels with 10000 events and analysis was performed by FCS Express.v5 Flow Cytometry data analysis software.

\section{Assessment of the mitochondrial membrane potential $\left(\Delta \Psi_{m}\right)$}

The effect of $\mathrm{P}_{\mathrm{N}}$ on the mitochondrial membrane potential, a crucial event in caspase-dependent apoptosis, was measured as previously described. ${ }^{16}$ CSCs $\left(1 \times 10^{4}\right.$ cells per well $)$ were treated with $\mathrm{P}_{\mathrm{N}}$ or $\mathrm{D}_{\mathrm{X}}$ for $48 \mathrm{~h}$. The cells were then stained with JC-1 $\left(1 \mu \mathrm{g} \mathrm{ml}{ }^{-1}\right)$ for $20 \mathrm{~min}$ at $37{ }^{\circ} \mathrm{C}$ in the dark and washed once with $1 \times$ PBS after staining. Fluorescence of JC-1 aggregates (red), indicative of healthy cells with functional mitochondria, and of monomers (green), indicative of apoptotic or unhealthy cells with collapsed mitochondria were measured at $590 \mathrm{~nm}$ with excitation at $580 \mathrm{~nm}$ and $527 \mathrm{~nm}$ with excitation at $510 \mathrm{~nm}$, respectively, using a FACS Calibur ${ }^{\mathrm{TM}}$. On average 10000 events were recorded and analysed by FCS Express.v5 Flow cytometry data analysis software.

\section{Annexin-V FITC staining}

CSCs $\left(1 \times 10^{4}\right.$ cells per well) were treated with $\mathrm{P}_{\mathrm{N}}$ in the presence or absence of NAC or $\mathrm{D}_{\mathrm{X}}$ for $48 \mathrm{~h}$ to determine apoptotic population. After the treatment, CSCs were collected by centrifugation at $2000 \mathrm{rpm}$ for $5 \mathrm{~min}$ at RT and washed once with $1 \times$ PBS. The cells were fixed in ice cold $4 \%$ paraformaldehyde (PFA) for $20 \mathrm{~min}$, washed once in $1 \times$ PBS and suspended in $500 \mu \mathrm{l}$ of $1 \times$ Annexin binding buffer [10× buffer composition: $0.1 \mathrm{M}$ HEPES/NaOH (pH 7.4), 1.4 M NaCl, and $25 \mathrm{mM} \mathrm{CaCl}_{2}$ ], stained with Annexin V-FITC reagent $\left(5 \mu \mathrm{l} ; 0.019 \mathrm{mg} \mathrm{ml}^{-1}\right)$ and incubated for $20 \mathrm{~min}$ at $37{ }^{\circ} \mathrm{C}$ in the dark. ${ }^{28}$ Stained cells were washed once with $1 \times$ PBS. Fluorescence (10 000 events) was monitored using the FL1 channel by a FACS Calibur ${ }^{\mathrm{TM}}$ and 
analysed using FCS Express.v5 Flow Cytometry data analysis software.

\section{PI staining}

CSCs cells $\left(1 \times 10^{4}\right.$ cells per well $)$ were treated with $\mathrm{P}_{\mathrm{N}}$ or $\mathrm{D}_{\mathrm{X}}$ for $48 \mathrm{~h}$ to determine late apoptosis cell death in the total population. Vehicle treated cells were included as controls. Cells were fixed with $4 \%$ ice cold PFA for $20 \mathrm{~min}$, washed with $1 \times$ PBS once and vortexed to remove clumping. The cells were suspended in $500 \mu \mathrm{l}$ of a PI master mix [prepared in $1 \times$ PBS buffer,
DNase-free RNAse $\left(100 \mu \mathrm{g} \mathrm{ml}^{-1}\right)$, PI $\left(40 \mu \mathrm{g} \mathrm{m}{ }^{-1}\right)$ and $0.1 \%$ Triton $\times 100]^{29}$ and incubated for $30 \mathrm{~min}$ at $37^{\circ} \mathrm{C}$ in the dark. Fluorescence was measured using a FACS Calibur ${ }^{\mathrm{TM}}$ at a $485 \mathrm{~nm}$ excitation wavelength with 10000 events, and analysed by FCS Express.v5 Flow Cytometry data analysis software.

\section{Statistical analysis}

GraphPad software (Chicago, USA) was used for statistical analyses. The levels of significance were calculated using a twoway analysis of variance (ANOVA) test (Dunnett's multiple
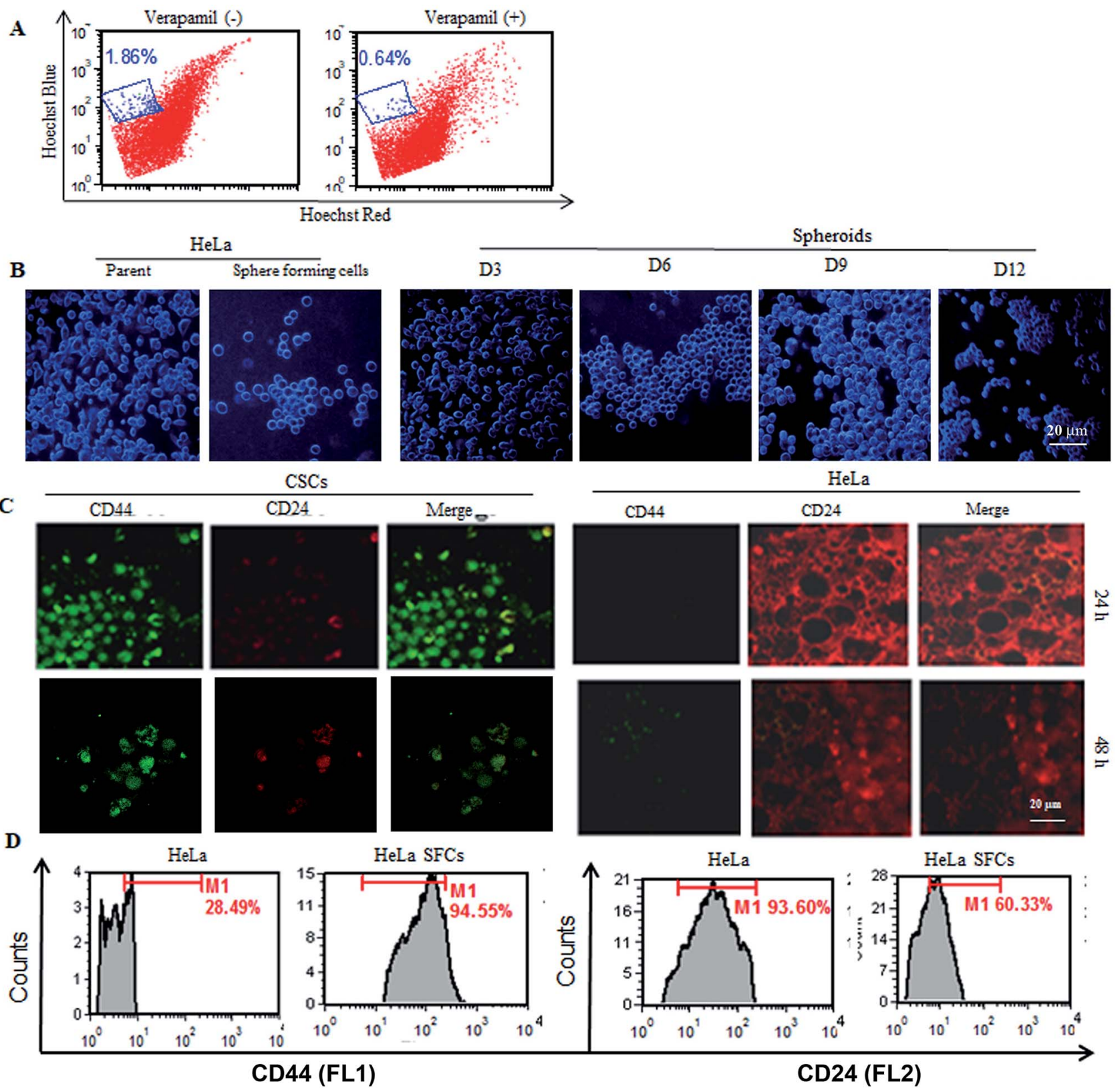

Fig. 1 Identification and validation of CSCs from HeLa cells. (A) Establishing the presence of the side population (SP) in HeLa cells. (B) Comparative morphological examination of sphere forming cells (SFC)/cancer stem-like cells (CSCs) and parent HeLa cells. Sphere forming cells derived from adherent populations of HeLa cells at different time intervals. (C) Expression analysis of cell surface markers (CD24 ${ }^{+}$and $C D 44^{+}$) in CSCs and HeLa cells after $48 \mathrm{~h}$ of seeding, visualized under a confocal microscope $(40 \times)$. (D) Quantitative analysis of CD44 ${ }^{+}$and CD24 expression on HeLa cells and CSCs by flow cytometry. 
comparison test). A ' $p$ ' value of less than $0.05(p<0.05)$ was considered as statistically significant with respect to the vehicletreated group. The results are expressed as mean $\pm \mathrm{SD}$ from at least three independent experiments, performed in triplicate.

\section{Results}

\section{Establishing the CSC population from the parent HeLa cells}

In order to establish the CSC population from the HeLa cells, it was necessary to observe the presence of the side population in the HeLa cells. The CSC population comprises signature surface molecules such as $\mathrm{ABC}$ transporter $\left(\mathrm{Ca}^{2+}\right.$ channel), which is extensively engaged in efflux action. The existence of a highly tumorigenic SP in parent HeLa cells was established by Hoechst dye efflux assay in the presence or absence of verapamil, a $\mathrm{Ca}^{2+}$ channel blocker. Verapamil inhibited the efflux of the dye from the SP. Approximately, a $1.86 \%$ SP (low efflux fluorescence) among the total number of HeLa cells was observed in the absence of verapamil. However, the presence of verapamil significantly reduced the low efflux fluorescence population to $0.64 \%$ (Fig. 1A). Thus, the reduction in SP in the presence of verapamil confirmed the presence of a SP in the parent HeLa cells. The CSC population generated from parent HeLa cells was first established and optimized in the presence of SFM and growth factors. The CSCs are known to continuously differentiate and make a cluster of heterogeneous mature cells. The side
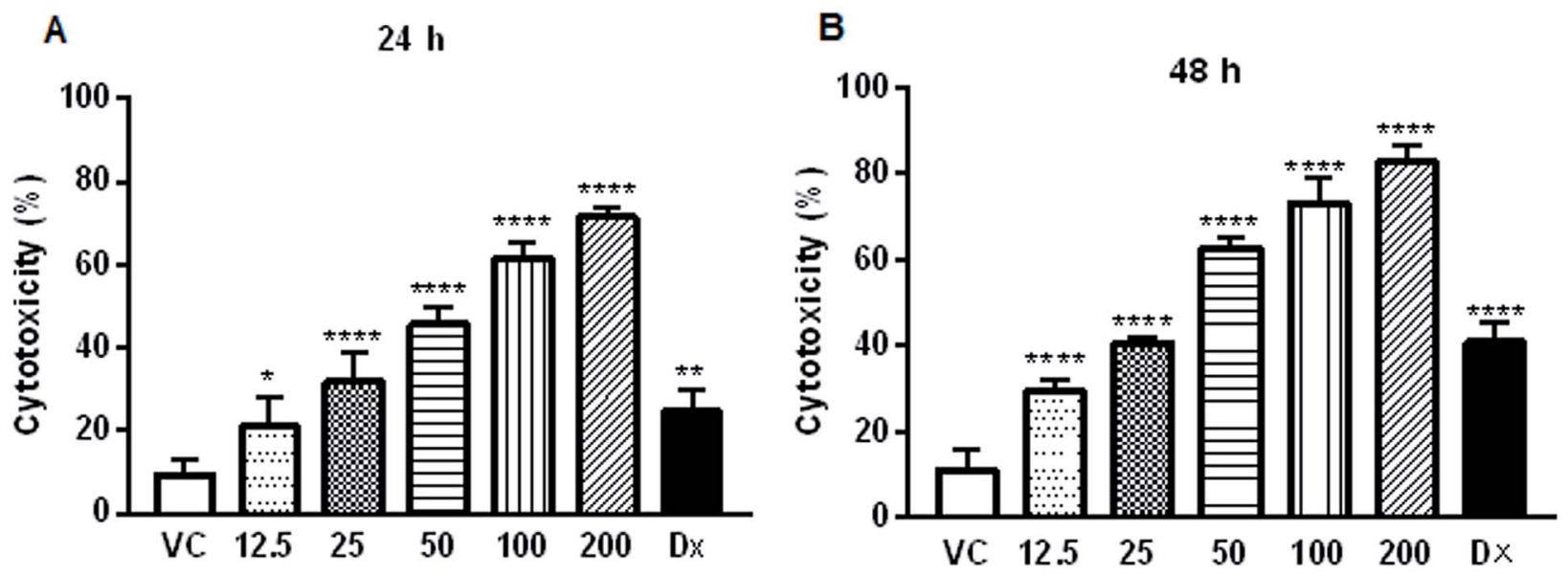

C
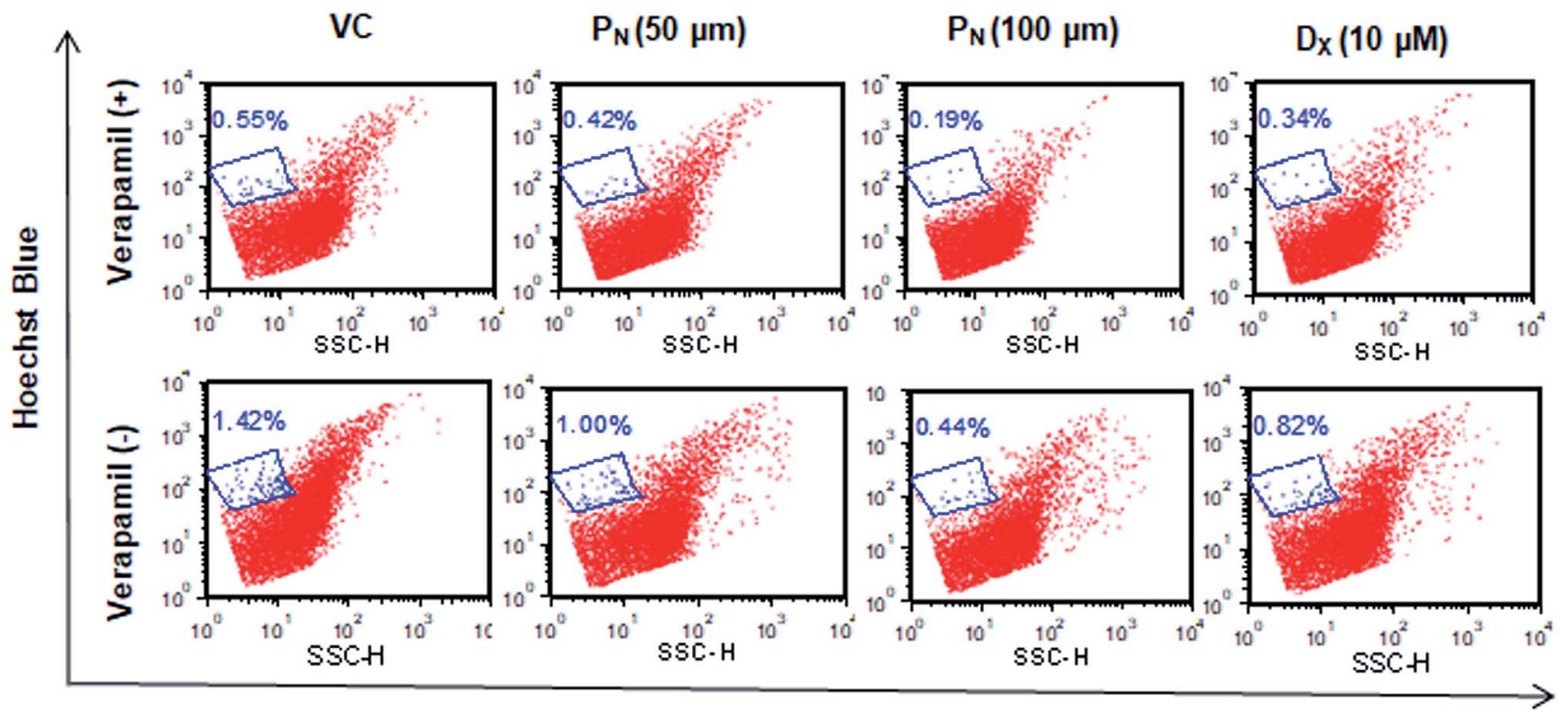

Hoechst Red

Fig. 2 Impact of $\mathrm{P}_{\mathrm{N}}$ on the CSC population and side population. MTT reduction assay to determine the cytotoxicity of $\mathrm{P}_{\mathrm{N}}$ in the CSC population at $24 \mathrm{~h} \mathrm{(A)}$ and $48 \mathrm{~h}$ (B) post treatment. The data represent the mean \pm SD of three independent experiments, performed in triplicate. Two-way ANOVA (Dunnett's multiple comparisons) was performed to calculate the statistical difference among all of the treated groups with respect to the vehicle treated group. $*=p \leq 0.05, * *=p \leq 0.01$, and $* * * *=p \leq 0.0001$. (C) The effect of $\mathrm{P}_{\mathrm{N}}$ on the SP in the presence and absence of verapamil analyzed using Hoechst 33342 staining by flow cytometry. $V C$, vehicle control; $P_{N}$, pinostrobin; $D_{x}$, doxorubicin. 
population present in the HeLa cells was significantly transformed into a compact cluster of cancer sphere cells (Fig. 1B). Microscopic examination of the cells showed that the formation of clusters of cancer sphere cells was initiated within 3 days and a progressive increase in the size of the spheres was observed with time (Fig. 1B). As is evident from Fig. 1B, the HeLa-CSCs continuously proliferated, made large number of clusters and differentiated into non-adherent spherical stem-like clusters. The CSCs generated from HeLa cells were also confirmed by expression analysis of cell surface markers on the CSC population (Fig. 1C). Furthermore, quantified high CD44 ${ }^{+}$expression $(94.55 \%)$ and relatively lower CD24 $4^{+}$expression $(28.94 \%)$
A

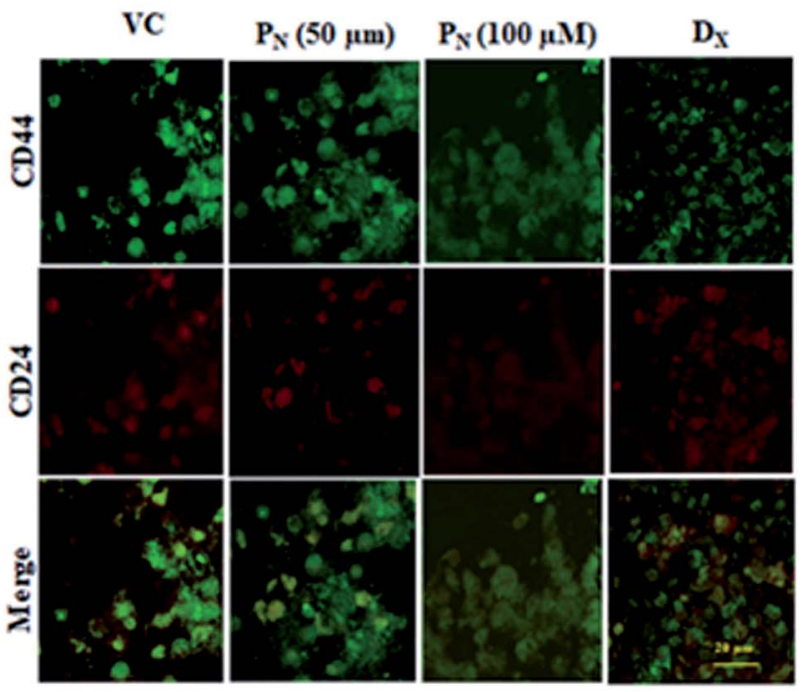

B

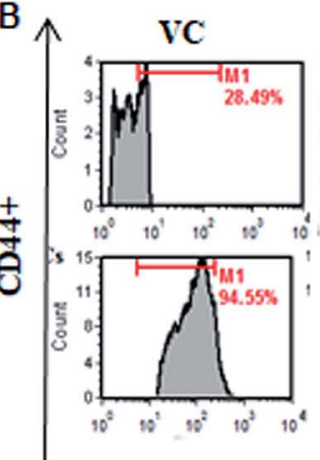

CSCs 48 h
$\mathrm{P}_{\mathrm{N}}(100 \mu \mathrm{M})$

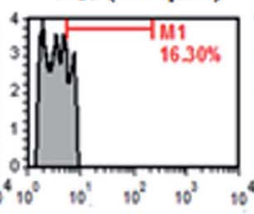

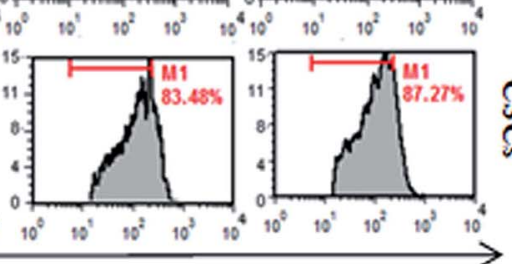

D
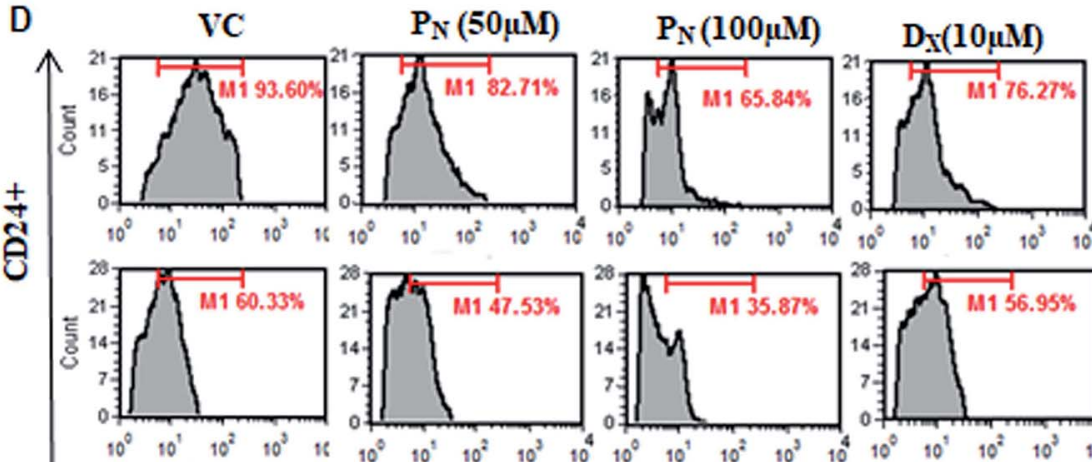

$\mathrm{D}_{\mathrm{x}}(10 \mu \mathrm{M})$

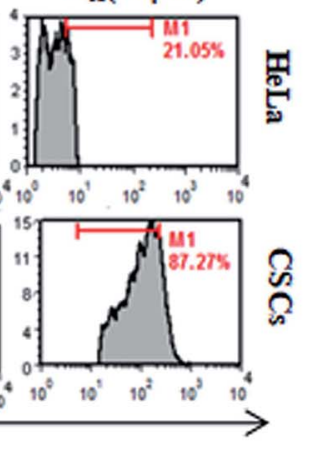

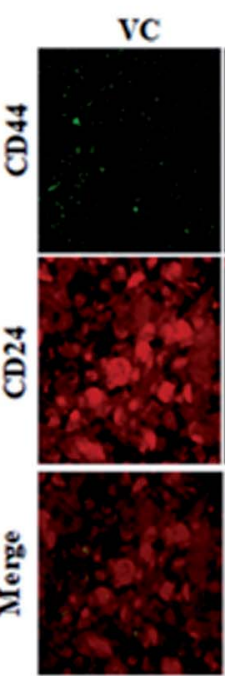

HeLa 48 h

C

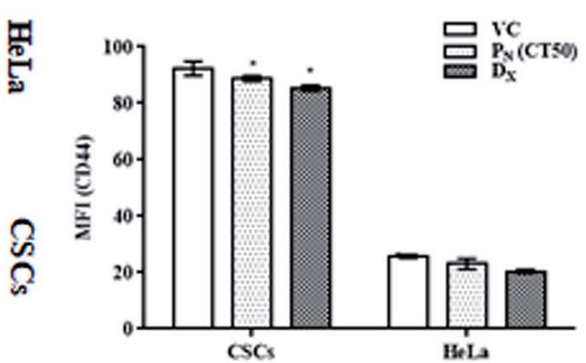

Fig. 3 Effect of $\mathrm{P}_{\mathrm{N}}$ on CD44 $4^{+}$and CD24 $4^{+}$expression in CSCs and HeLa cells. (A) HeLa cells and CSCs, treated with the vehicle and different concentrations of $P_{N}$ and $D_{x}$ for 48 h, were stained with FITC-conjugated anti-CD44 and PE-conjugated anti-CD24 antibodies and visualized $(40 \times)$ under a confocal microscopy. (B and D) Flow cytometric analysis of CD 44 ${ }^{+} \&$ CD24 $4^{+}$expression in $\mathrm{P}_{\mathrm{N}}$-treated $(50 \mu \mathrm{M}, 100 \mu \mathrm{M}) \mathrm{HeLa}$-CSCs at $48 \mathrm{~h}$ post-treatment. (C and E) Mean fluorescence intensity of $C D 44^{+}$and $C D 24^{+}$HeLa cells and CSCs treated with $P_{N}$. VC, vehicle control; $P_{N}$, pinostrobin; $D_{x}$, doxorubicin. 
were observed on HeLa-sphere forming cells, whereas the parent HeLa cells showed low CD $44^{+}(60.33 \%)$ and high CD24 (93.60\%) expression (Fig. 1D). These results confirmed the authenticity of the CSC cultures generated from the HeLa cells.

\section{Regeneration of the HeLa cells from SFCs and spheroids}

The authenticity of the CSCs was further confirmed by checking their ability to generate HeLa cells. The self-renewal ability of SFCs/CSCs and spheroids to regenerate parent HeLa cells was evaluated by growing them in constituted DMEM. The SFCs adhered to the surface of the culture flask, exhibiting a similar morphology to that of the parent HeLa cells within 5 days. Furthermore, the self-renewal activity of the SFCs was also validated by the formation of spheroids. Spheroids were formed as a cluster of heterogeneous cells after long culturing of SFCs. When spheroids of 3 and 5 days were cultured in constituted DMEM, the cells quickly adopted that same morphology as that of the parent HeLa cells within 4 days (Fig. S1†). Thus, these results indicated that both SFCs and spheroids derived from them adopted parent HeLa cell morphology.

\section{$\mathbf{P}_{\mathrm{N}}$ decreases cell viability and modulates side population}

The effect of $\mathrm{P}_{\mathrm{N}}$ on the cell viability of CSCs was assessed by MTT assay. As shown in Fig. $2 \mathrm{~A}, \mathrm{P}_{\mathrm{N}}$ treatment significantly inhibited CSC population cell viability in a dose-dependent manner at concentrations starting from $12.5 \mu \mathrm{M}$ (Fig. $2 \mathrm{~A}$ ). $\mathrm{D}_{\mathrm{X}}$ treatment, included as a reference control, also resulted in decreased cell viability of the CSCs. Based on the cell viability
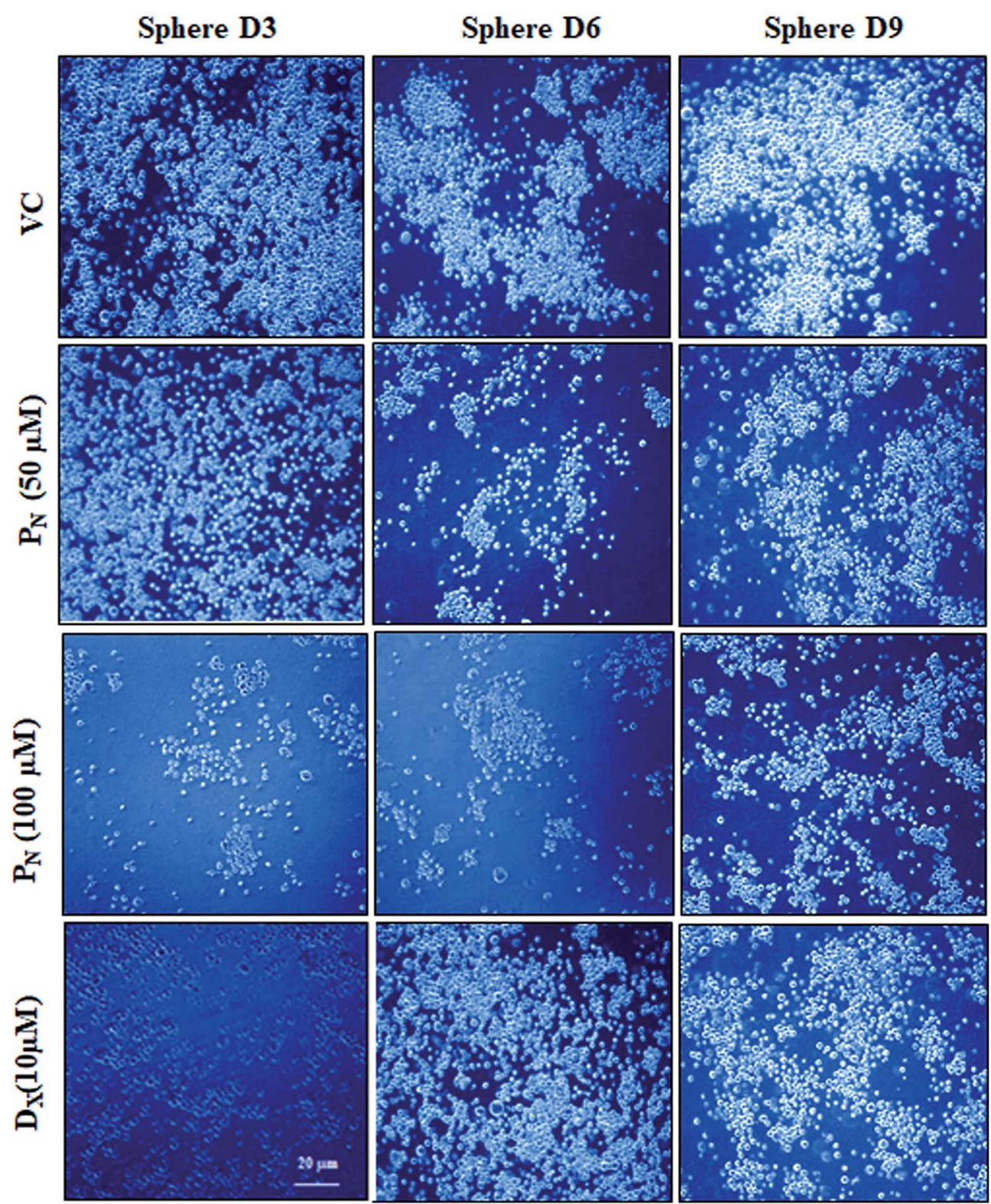

Fig. 4 Effect of $P_{N}$ on sphere formation efficiency. The morphology and number of spheres were examined microscopically (20x) at different time points after $P_{N}$ treatment. $V C$, vehicle control; $P_{N}$, pinostrobin; $D_{X}$, doxorubicin. 
data of the $\mathrm{P}_{\mathrm{N}}$-treated CSCs, $50 \mu \mathrm{M}$ of $\mathrm{P}_{\mathrm{N}}$ was used for subsequent experiments. To establish if $\mathrm{P}_{\mathrm{N}}$ affected the side population in the HeLa cells, the effect of $\mathrm{P}_{\mathrm{N}}$ treatment on the SP in the HeLa cells in the presence or absence of verapamil was also investigated. $\mathrm{P}_{\mathrm{N}}(50 \mu \mathrm{M} \& 100 \mu \mathrm{M})$ significantly reduced the SP to $1 \%$, and $0.44 \%$ in comparison to that observed in vehicle treated cells $(\sim 1.42 \%)$ in the absence of verapamil. In the presence of verapamil, the percentage of SP was further reduced to $0.42 \%$ and $0.19 \%$ at 50 and $100 \mu \mathrm{M}$ of $\mathrm{P}_{\mathrm{N}}$, respectively, as compared to the vehicle treated cells $(0.55 \%)$ (Fig. 2C). Thus, $\mathrm{P}_{\mathrm{N}}$ was competent in reducing the SP number, either in the absence or presence of verapamil in a dose-dependent manner.

\section{$\mathbf{P}_{\mathrm{N}}$ alters the expression of CSC cell surface markers}

Cancer stem cells proficiently express unique surface markers, including $\mathrm{CD}_{4} 4^{+}, \mathrm{CD} 24^{+}$and ATP binding cassette (ABC) transporters. A reduction in the number of viable CSCs by $\mathrm{P}_{\mathrm{N}}$, as evident from MTT assay, was confirmed by the analysis of the expression of cell surface markers on the CSC population. A higher expression of $\mathrm{CD} 44^{+}$with negligible expression of $\mathrm{CD} 24^{+}$ is characteristic of CSCs, whereas HeLa cells express higher
$\mathrm{CD} 24^{+}$with minimal CD $44^{+}$. Confocal microscopy of the treated cells clearly showed a decrease in the green fluorescence of FITC in the $\mathrm{P}_{\mathrm{N}}$-treated CSCs, indicating decreased expression of $\mathrm{CD} 44^{+}$when compared to vehicle-treated CSCs (Fig. 3A). Likewise, a decrease in the red fluorescence of the PE stain indicated a decreased expression of $\mathrm{CD} 24^{+}$in comparison to vehicle treated HeLa cells (Fig. 3A). The change in the expression of the surface markers on the CSCs and HeLa cells was also observed after $24 \mathrm{~h}$ with evident disintegration of the spheroids in the $\mathrm{D}_{\mathrm{X}}$ treated cells (Fig. S2†). However, after $48 \mathrm{~h}$, the change was prominent, as evident from the increased fluorescence on $\mathrm{P}_{\mathrm{N}}$ exposure. Thus, $\mathrm{P}_{\mathrm{N}}$ adversely affected both the HeLa cells and its CSCs.

Quantitative analysis of CD $44^{+}$and $\mathrm{CD} 24^{+}$on the CSCs and HeLa cells by flow cytometry further confirmed the microscopic results. As evident from Fig. $3, \mathrm{P}_{\mathrm{N}}(100 \mu \mathrm{M})$ reduced $\mathrm{CD}_{4} 4^{+}$in both the CSCs and HeLa cells to 83.48 and $16.30 \%$ compared to vehicle treated CSCs (94.55\%) and HeLa cells (28.49\%) (Fig. 3B). A decrease in the CD44 ${ }^{+}$CSC population was observed in $\mathrm{P}_{\mathrm{N}}$ treated CSCs (Fig. 3C). The vehicle treated CSCs showed $60.33 \%$ CD $24^{+}$cells, whereas in $\mathrm{P}_{\mathrm{N}}$-treated $(100 \mu \mathrm{M})$ cells, their expression was reduced to $35.87 \%$. Likewise, a decrease in the
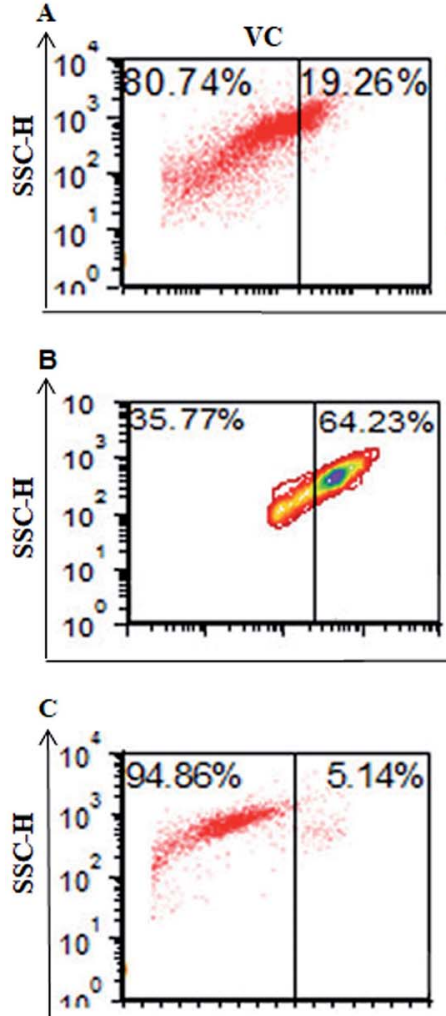
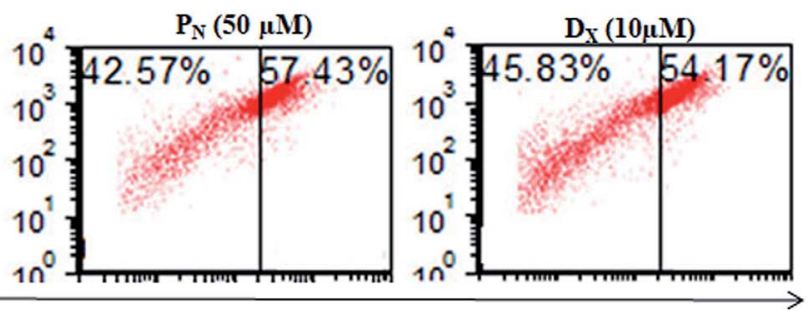

FL2-H (DCF)

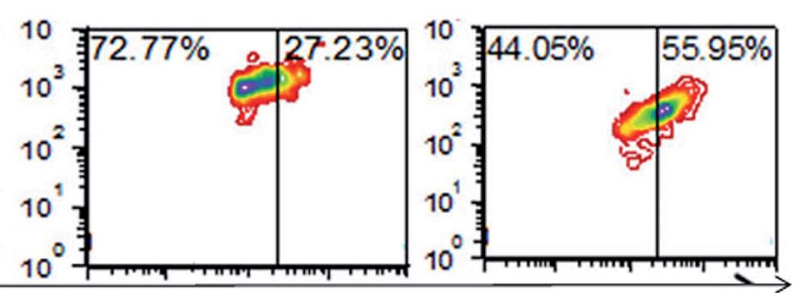

FLl-H (Cardiolipin Oxidation)
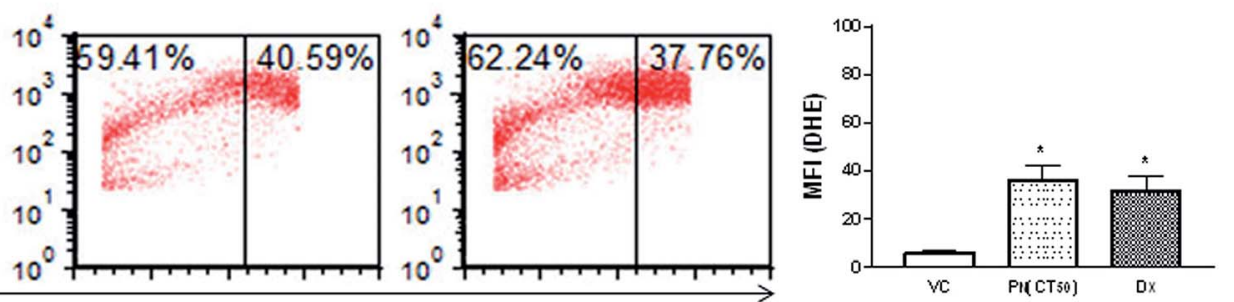

FL2-H (Hydroethidine Oxidation)

Fig. 5 Effect of $\mathrm{P}_{\mathrm{N}}$ on ROS production, cardiolipin oxidation and DNA damage. (A) Flow cytometric analysis of the ROS production using DCFH staining in the $\mathrm{P}_{\mathrm{N}}$-treated CSC population. (B) Analysis of cardiolipin oxidation using 10-nonyl acridine orange (NAO) staining by flow cytometry in the $\mathrm{P}_{\mathrm{N}}$ treated CSC population. (C) Flow cytometric analysis showing oxidation of hydroethidine (HE) by ROS in $\mathrm{P}_{\mathrm{N}}$ treated CSCs. The figures show the representative dot plots for each analysis. The bar diagrams on the right show the mean fluorescence intensity of the respective fluoroprobe in the CSCs subjected to different treatments. Significance ( $p$ value) levels were calculated with respect to vehicle treated CSCs (VC) using two-way ANOVA (Dunnett's multiple comparisons) * $=p \leq 0.05, * *=p \leq 0.01, * * *=p \leq 0.001$ and $* * * *=p \leq 0.0001$. VC, vehicle control; $P_{N}$, pinostrobin; $D_{x}$, doxorubicin. 
expression of $\mathrm{CD}_{4} 4^{+}$and $\mathrm{CD} 24^{+}$was noted in $\mathrm{P}_{\mathrm{N}}$-treated HeLa cells. $\mathrm{P}_{\mathrm{N}}$ exposure reduced the expression levels of CD44 $4^{+}$and $\mathrm{CD} 24^{+}$to 16.30 and $65.84 \%$, respectively in HeLa cells in comparison to vehicle treated cells (CD44 ${ }^{+}$and $\mathrm{CD} 24^{+}, 28.49 \%$ and $93.60 \%$, respectively) after $48 \mathrm{~h}$ (Fig. 3D and E). The expression of $\mathrm{CD}_{4} 4^{+}$and $\mathrm{CD} 24^{+}$was also found to be lower in $\mathrm{D}_{\mathrm{X}^{-}}$ CSCs and HeLa cells treated with $\mathrm{D}_{\mathrm{X}}$ for $48 \mathrm{~h}$, respectively.

\section{$P_{N}$ inhibits the sphere formation efficiency (SFE) of CSCs and alters the morphology of the spheres}

Since CSCs form spheres that contain tumorigenic cells, it was of interest to know if $\mathrm{P}_{\mathrm{N}}$ affected the sphere formation. For this, the effect of $\mathrm{P}_{\mathrm{N}}$ on the sphere formation efficiency of the HeLaCSCs was analysed at different time intervals. As evident from Fig. 4, there was an increase in the number of cell clusters/ spheroids with time in the untreated/vehicle treated cells. $\mathrm{P}_{\mathrm{N}^{-}}$ treatment of CSCs resulted in a relatively lower number of cell clusters and decreased the sphere and spheroid formation when compared to the vehicle control. Likewise, $\mathrm{D}_{\mathrm{X}}$-treated CSCs also showed a relatively lower number of compact spheroids as compared to the vehicle treated group and the spheroids appeared to be disintegrated into smaller individual spheres. Thus, the sphere formation efficiency was significantly reduced in $\mathrm{P}_{\mathrm{N}}$-treated CSCs when compared to vehicle treated cells. Morphological examination of the spheres showed a timedependent increase in the size of the spheres and that they formed symmetric prototypical spheroids that indicated the self-renewal function of normal stem cells, in vehicle treated cells. On the other hand, in the $\mathrm{P}_{\mathrm{N}^{-}}$-treated CSCs as well as $\mathrm{D}_{\mathrm{X}^{-}}$ treated CSCs, a loss in the compact spheroid structure was observed. $\mathrm{P}_{\mathrm{N}}$-treatment resulted in complete disruption of the morphology of a single sphere with its outer cell membrane significantly disintegrated at $48 \mathrm{~h}$. D $\mathrm{D}_{\mathrm{x}}$-treated spheres also showed disintegration of the membrane integrity. Vehicletreated CSCs showed intact spheres similar to those seen in untreated CSCs (Fig. 4).

\section{$P_{N}$ enhances ROS generation}

Reactive oxygen species (ROS) production was analysed in $\mathrm{P}_{\mathrm{N}}$ treated CSCs by DCFH-DA (Fig. 5A). $\mathrm{P}_{\mathrm{N}}$-treated $(50 \mu \mathrm{M})$ CSCs exhibited higher fluorescence events of DCF $(57.43+3.54 \%)$ in comparison to vehicle-treated CSCs $(19.26+0.21 \%)$. Higher DCF fluorescence in $\mathrm{P}_{\mathrm{N}}$-treated cells is an indicator of ROS production in CSCs. The site of ROS production was analysed

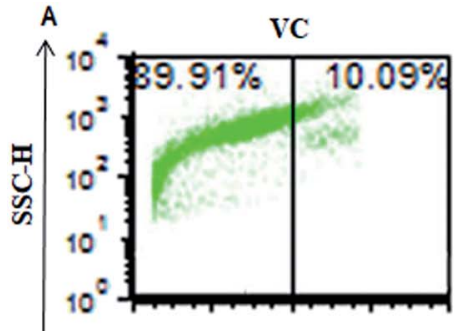

B

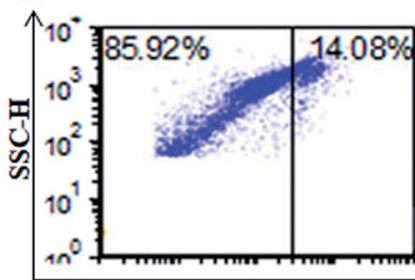

C

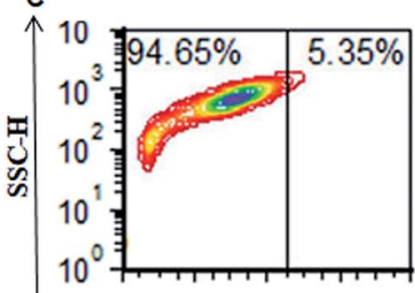

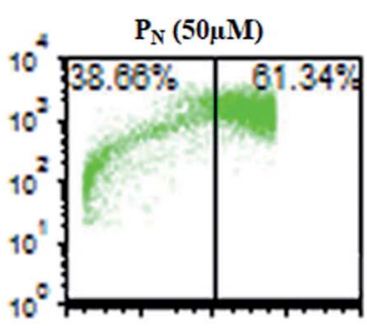

FL1-H (AnnexinV FITC)

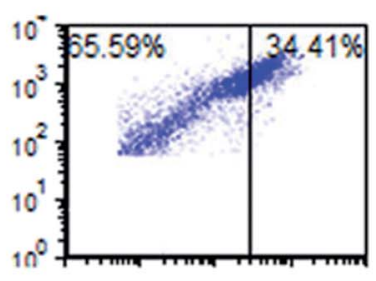

FL2-H ( PI)

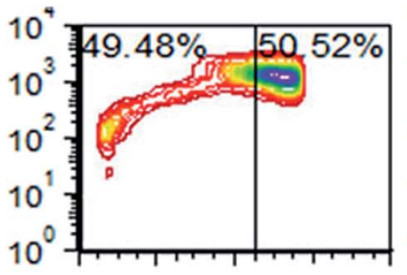

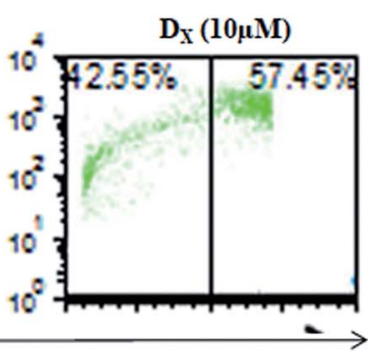
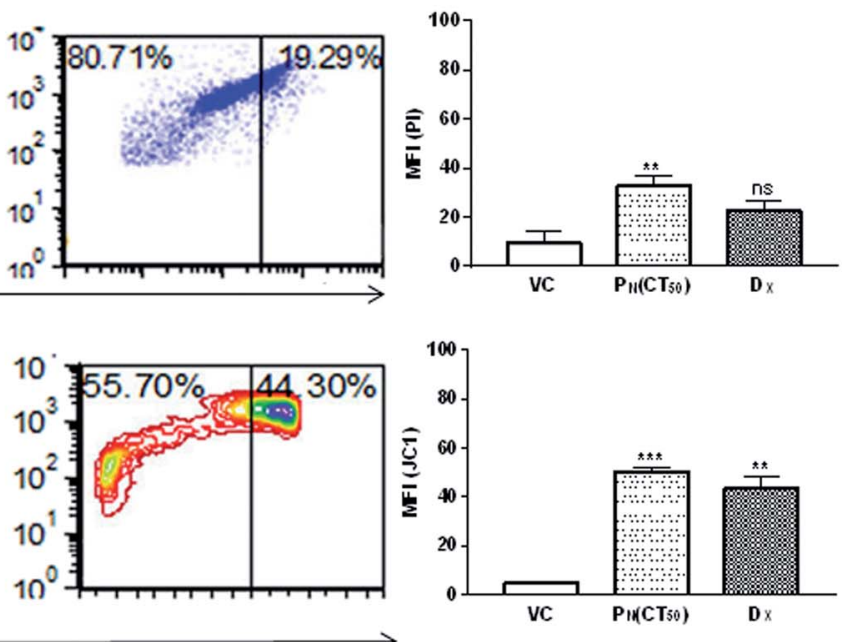

FL1-H (JC-1- Green fluorescence)

Fig. 6 Measurement of apoptotic/necrotic cell populations and change in the mitochondrial membrane potential in $\mathrm{P}_{\mathrm{N}}$-treated CSCs. (A) Annexin-V-FITC staining to determine apoptotic cell population in $\mathrm{P}_{\mathrm{N}}$ treated CSCs population. (B) Flow cytometric analysis of PI stained CSCs to determine late apoptotic cell population. (C) Flow cytometric analysis of the change in the mitochondrial membrane potential $\left(\Delta \Psi_{\mathrm{m}}\right)$ in the $\mathrm{P}_{\mathrm{N}}$ treated CSCs population using JC-1 probes. The bar diagrams on the right show the mean fluorescence intensity of the respective fluoroprobe in the CSCs subjected to different treatments. Significant difference ( $p$ value) was calculated using two-way ANOVA (Dunnett's multiple comparisons with respect to the vehicle treated group). $*=p \leq 0.05, * *=p \leq 0.01, * * *=p \leq 0.001$ and $* * * *=p \leq 0.0001$. VC, vehicle control; $P_{N}$, pinostrobin; $D_{x}$, doxorubicin. 
using 10-nonyl acridine orange (NAO) dye. $\mathrm{P}_{\mathrm{N}}$-treated CSCs showed lower binding affinity of NAO with cardiolipin $(27.71+$ $4.40 \%)$ when compared to vehicle-treated CSCs $(64.23+2.0 \%)$ at $48 \mathrm{~h}$ of treatment (Fig. 5B). The consequences of ROS production in $\mathrm{P}_{\mathrm{N}}$-treated CSCs were analysed using HE. Fig. 5C shows the red fluorescence of ethidium bromide that binds to DNA of damaged cells. $\mathrm{P}_{\mathrm{N}}$-treated CSCs showed presence of DNA fragmentation indicated by greater red fluorescence events $(40.59+$ $6.15 \%)$. DNA fragmentation was found to increase with time and increasing dose of $\mathrm{P}_{\mathrm{N}}$.

$\mathbf{P}_{\mathrm{N}}$ treatment promotes apoptotic cell population and depolarization of the mitochondrial membrane potential $\left(\Delta \Psi_{\mathbf{m}}\right)$

Cell membrane integrity is an indicator of a healthy cell. In apoptotic cells, phosphatidylserine, an inner cell membrane protein, is externalized from the inner side to the outer side of the cells, to which Annexin $\mathrm{V}$ is able to bind. In order to see if $\mathrm{P}_{\mathrm{N}}$ affects the cell membrane integrity, FITC-Annexin V staining was carried out. $\mathrm{P}_{\mathrm{N}}$-treated cells showed greater phosphatidylserine exclusion in the form of Annexin V-FITC fluorescence events in CSCs (61.34 $\pm 3.37 \%)$ indicating early apoptotic cell population, in comparison to vehicle $(\sim 10 \%)$ treated cells at $48 \mathrm{~h}$ (Fig. 6A). Thus, externalization of phosphatidylserine was significantly increased in $\mathrm{P}_{\mathrm{N}}$-treated cells in a time dependent manner, indicating disruption of membrane integrity.
DNA fragmentation was analysed by PI staining to determine the late apoptotic cell population. CSCs exposure to $\mathrm{P}_{\mathrm{N}}$ resulted in an increase in PI-stained nuclei also with red fluorescence events at $34.41 \pm 3.72 \%$, compared to vehicle treated cells with PI fluorescence events at $14.08 \pm 4.43 \%$ (Fig. 6B). The greater number of stained nuclei in $\mathrm{P}_{\mathrm{N}}$-treated CSCs indicated the disintegration of nuclear membrane. Integrity of the mitochondrial membrane is absolutely necessary for the normal metabolic functions of cells. Hence, the mitochondrial membrane potential was analysed using a cationic carbocyanine JC-1 probe in vehicle-treated and $\mathrm{P}_{\mathrm{N}}$ treated CSCs. Fig. 6C shows that $\mathrm{P}_{\mathrm{N}}$-treated CSCs showed a higher number of JC-1 monomer fluorescence events $(50.52 \pm 1.71)$ in comparison to that observed in vehicle treated cells (fluorescence events $\sim 5 \%$ ) at $48 \mathrm{~h}$. $\mathrm{D}_{\mathrm{X}}$, used as a positive control, also resulted in the formation of JC-1 monomer fluorescence events $(\sim 4 \%)$ in CSCs. The vehicle-treated cells showed high $\Delta \Psi_{\mathrm{m}}$ with intense red fluorescence and exhibited fewer JC-1 monomers with intact membranes.

\section{NAC rescues $\mathbf{P}_{\mathbf{N}}$-induced ROS-mediated apoptosis in CSCs}

To confirm the role of ROS in $\mathrm{P}_{\mathrm{N}}$-induced cell death, the ROS scavenger NAC was used. For this, the CSCs were incubated with $5 \mathrm{mM}$ NAC for $5 \mathrm{~h}$ prior to the addition of $50 \mu \mathrm{M} \mathrm{P}_{\mathrm{N}}$ and allowed to grow for a further $48 \mathrm{~h}$. As is evident from the figure, pretreatment with NAC resulted in $\sim 30 \%$ reduction in

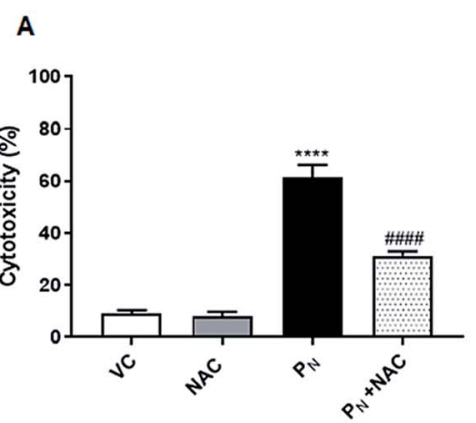

D

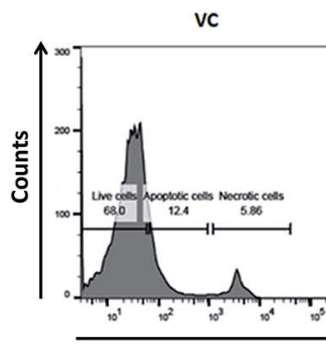

B

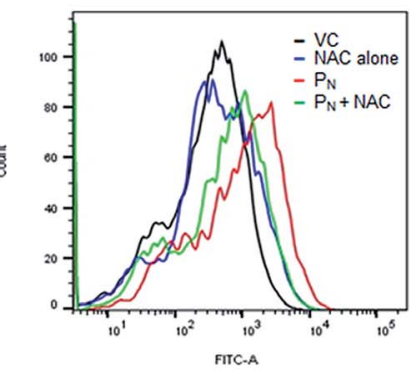

C

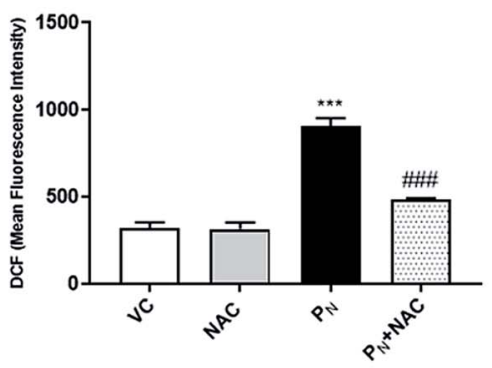

E
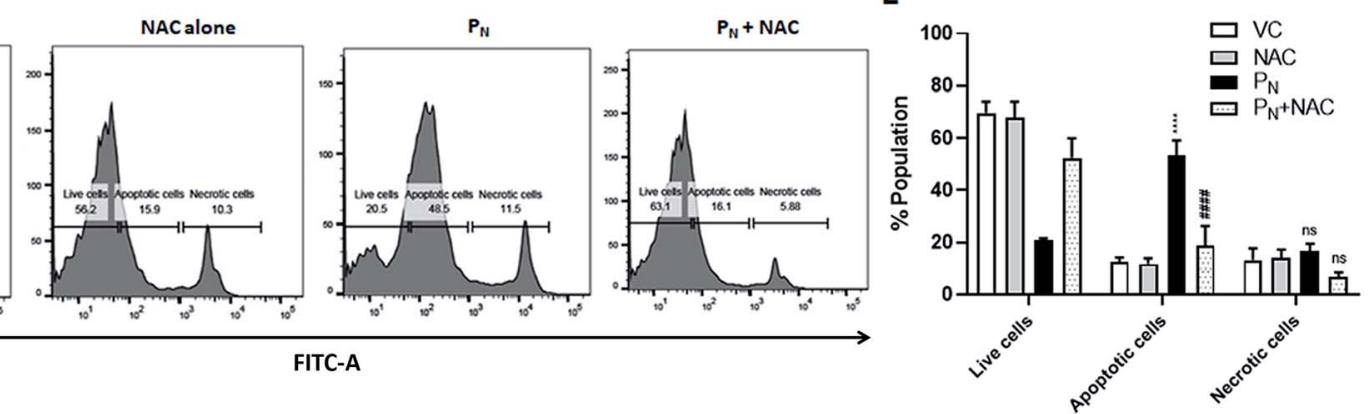

Fig. 7 Role of ROS in apoptosis induced by $\mathrm{P}_{\mathrm{N}}$. CSCs were pre-incubated with NAC $(5 \mathrm{mM})$ for $5 \mathrm{~h}$, followed by treatment with $\mathrm{P}_{\mathrm{N}}(50 \mu \mathrm{M})$ for 48 h. (A) Cell toxicity (\%) was measured by MTT assay. (B) Overlay histogram showing ROS generation in $P_{N}$-treated and NAC-treated groups. (C) Bar diagram representing the effect of NAC on $P_{N^{-}}$-induced ROS generation. (D and $E$ ) NAC reduced apoptosis resulting in a reduction of the $P_{N^{-}}$ treated CSC population using an Annexin-V-FITC apoptosis detection kit (Biovision), as per manufacturer's instructions. All of the FACS experiments were carried out on a BD FACSAriaTM III cell sorter (BD Biosciences). Ordinary one-way ANOVA (Dunnett's multiple comparisons test) was performed to calculate the statistical difference $(p \leq 0.05)$. (*) compared with vehicle control cells, whereas \# represents the significance compared to $\mathrm{P}_{\mathrm{N}}$-treated cells. NS: non-significant, VC: vehicle control, $\mathrm{P}_{\mathrm{N}}$ : pinostrobin, NAC: $n$-acetyl cysteine. 
cytotoxicity (Fig. 7A) when compared to the cells treated with $\mathrm{P}_{\mathrm{N}}$ alone $(\sim 60 \%)$. Since $\mathrm{P}_{\mathrm{N}}$ treatment resulted in increased ROS production, ultimately leading to cell death, ROS production in the cells pre-treated with NAC was also estimated. Fig. 7B and C clearly show a $53.8 \%$ reduction in the ROS levels assessed by DCFH-DA staining in the cells pre-treated with NAC in comparison to those treated with $\mathrm{P}_{\mathrm{N}}$ alone. A reduction in cell death accompanied by decreased ROS levels in the NACpretreated cells clearly indicate that NAC was able to rescue the CSCs from the ill effects of ROS generated due to $\mathrm{P}_{\mathrm{N}}$ treatment. Apoptosis assay using FITC conjugated Annexin V also confirmed that NAC inhibited $\mathrm{P}_{\mathrm{N}}$-induced apoptosis in CSCs (Fig. 7D and E). Pre-treatment with NAC resulted in a significant decrease in the apoptotic cell population $(\sim 20 \%)$ when compared to the $\mathrm{P}_{\mathrm{N}}$-treated cells alone (52\%). No significant changes in the necrotic population in the NAC pre-treated group were observed in comparison with the $\mathrm{P}_{\mathrm{N}}$-treated group. These data validated that $\mathrm{P}_{\mathrm{N}}$ inhibited cell proliferation and caused ROS-mediated apoptosis in the CSC population.

\section{Discussion}

Despite the availability of various therapies such as chemotherapy, radiotherapy and surgical intervention for the treatment of cancer, the incidence of relapse and subsequent mortality due to various cancers have been reported to increase. The primary cause of this recurrence has been attributed to the SP of cancer cells recognised as the CSC population, which are often resistant to existing therapies. Therefore, it is hypothesized that successful treatment of cancer does not only depend on the main tumor mass, but also on highly resistant CSCs. The existence of CSCs suggests that tumor development and metastasis are driven by the SP of parent cancer cells, which are responsible for tumor initiation, growth and recurrence. Therefore, the targeting of CSCs is gaining attention in devising new treatment strategies for cancer. Indeed, combination therapies that target both stem cells and tumor cells have been proven to be more effective in the treatment of breast cancer. ${ }^{29}$

Traditional medicines systems including Unani, Ayurveda and Siddha have used formulations derived from plants and marine sources for the treatment of different ailments with minimal toxicity. Indeed, a number of chemotherapeutic agents such as taxol and vinblastine, currently used for the treatment of cancer, are derived from plants. ${ }^{12}$ The use of molecules/compounds derived from dietary substances that are part of the daily diet for the prevention and treatment of cancer would possibly provide an alternate strategy without the adverse effects associated with currently available therapies. With respect to targeting cancer cells, a number of compounds have shown selective toxicity to cancer stem cells in in vivo models. ${ }^{30} \mathrm{~A}$ few of these compounds are present in our daily diet, including curcumin, resveratrol, epigallocatechin gallate (EGCG), vitamin A and its precursors, isothiocyanate-sulforaphane, and various other flavonoids. ${ }^{30-32}$ Curcumin and EGCG have been reported to downregulate the self-renewal ability of CSCs by modulating associated pathways in an in vitro model. ${ }^{33}$ Similarly, resveratrol has also been reported to significantly reduce the nuclear localisation of $\beta$-catenin, important for normal signalling in CSC maintenance. ${ }^{34}$ Dietary agents have been reported to overcome CSC-dependent drug resistance. ${ }^{35}$ Treatment with plant-derived quercetin showed greater inhibition of tumor growth, indicating the influence on drug resistant cells in comparison to control mice, suggesting a lower proportion of chemotherapyresistant CSCs. ${ }^{30}$ Some flavonoids show synergistic action in different cancer cells, whereas some show specific toxicity against certain types of cells. ${ }^{36-38}$ Thus, there is a need to search for molecules that have anti-cancer activity for a variety of cancer cells together with the ability to inhibit CSC proliferation.

$\mathrm{P}_{\mathrm{N}}$, a flavonoid present in a number of dietary compounds, has been shown to inhibit the growth and proliferation of a variety of cancer cells. ${ }^{13-16}$ Previous findings from our laboratory have demonstrated the anticancer potential of $\mathrm{P}_{\mathrm{N}}$ through the inhibition of topoisomerase I activity, control of cell proliferation, and oxidative-stress induced cell death in HeLa cells. ${ }^{16,17} \mathrm{P}_{\mathrm{N}}$ efficiently induced apoptosis in HeLa cells through ROSmediated activation of extrinsic and intrinsic signalling pathways, as well as ROS-mediated mitochondrial damage. ${ }^{16}$ Stem cells contain own signature molecules like ABC membrane transporter proteins that efflux certain lipophilic drugs and are recognized as the $\mathrm{SP} .{ }^{39} \mathrm{~A}$ few $\mathrm{ABC}$ membrane transporter proteins act as $\mathrm{Ca}^{2+}$ channels, increasing the cellular uptake of $\mathrm{Ca}^{2+}$ and activating $\mathrm{Ca}^{2+}$ dependent proteases (e.g. calpain) and endonuclease(s), which leads to DNA fragmentation and apoptosis. ${ }^{40,41}$ We first demonstrated the existence of highly tumorigenic CSCs or side population in parental HeLa cells by Hoechst staining in the presence of verapamil, a $\mathrm{Ca}^{2+}$ channel blocker, which would prevent the efflux of Hoechst dye from the SP.

Our results confirmed that the HeLa cells used in the study did contain a SP or CSCs. After confirming the presence of the SP or CSCs in the parental HeLa cells, sphere forming cells (SFCs) or CSCs were successfully established from HeLa cells in vitro to assess the effect of $\mathrm{P}_{\mathrm{N}}$ on their self-renewal properties. Compact clusters of cancer sphere cells were non-adherent and spherical with a morphology different from that of the parent HeLa cells. A progressive increase in their diameter clearly indicated their high proliferative and self-renewal ability. Similar uniformity in sphere formation and maturation has also been reported in CSCs derived from breast cancer epithelial cell lines including MCF-7 and MDAMD-231, and various sarcoma and brain tumors. ${ }^{42-44} \mathrm{P}_{\mathrm{N}}$ treatment showed significant cytotoxicity towards CSCs in a dose and timedependent manner. This is evident from the reduction in the number and size of the spheroids and overall decrease in sphere formation efficiency. Our results suggest that HeLa cells contain a $\mathrm{P}_{\mathrm{N}}$-sensitive CSC population. Our results are in agreement with those of Tang et al., ${ }^{45}$ who showed that EGCG, another flavonoid, inhibited the growth of CSCs derived from human prostate cancer cells (PC-3 and LNCaP) in a dose-dependent manner. Likewise, a significant reduction in tumor volume in a MDA-MB-231 mammosphere model with a $\mathrm{CD} 44^{\text {high }} / \mathrm{CD} 24^{\text {low }}$ phenotype was observed after curcumin administration..$^{30}$

Like the CSCs derived from human colon carcinoma HT29 cells ${ }^{20}$ and ovarian carcinoma SKOV3 cells, ${ }^{21} \mathrm{D}_{\mathrm{X}}$ also inhibited cell proliferation of the CSCs derived from HeLa cells in the present study. Previous studies have shown that CSC subpopulations can be identified, isolated from various different tumors by exploiting 
cell-surface markers such as $\mathrm{CD}_{4} 4^{+}$and $\mathrm{CD} 24^{+}$in ovarian and mammospheres from breast cancer cell lines. ${ }^{50}$ These specific signature molecules or cell surface markers have been correlated with disease determination. ${ }^{46}$ The $\mathrm{CD} 24^{+}$population is involved in the formation of sphere-like bodies, cell proliferation, differentiation, promotion of tumour growth, and increases resistance towards chemotherapeutic drugs, whereas the $\mathrm{CD} 44^{+}$population is engaged in cancer promotion, metastasis and cancer cell growth. ${ }^{47} \mathrm{Gu}$ and his colleagues reported HeLa-SFC/CSC populations that expressed $\mathrm{CD} 44^{\text {high }} / \mathrm{CD} 24^{\text {low }}$ cell-surface markers and showed drug resistance. ${ }^{19}$ A reduction in the CSC population upon $\mathrm{P}_{\mathrm{N}}$-treatment was therefore confirmed by analysis of CSC-specific cell surface markers on HeLa-CSCs. As expected, the HeLa-CSCs showed high $\mathrm{CD}_{4} 4^{+}$and low $\mathrm{CD}_{2} 4^{+}$expression, whereas the parental HeLa cells showed lower $\mathrm{CD}_{4} 4^{+}$and higher $\mathrm{CD} 24^{+}$ expression. ${ }^{19}$ Thus, both the morphological examination and expression analysis of the cell surface markers confirmed the identity of the HeLa-CSCs and their stem-like properties. $\mathrm{P}_{\mathrm{N}^{-}}$ treatment resulted in a significant decline in the expression of $\mathrm{CD}_{4} 4^{+}$and $\mathrm{CD} 24^{+}$in HeLa cells as well as HeLa-CSCs, although the extent of reduction was more in CSCs than that observed in parent HeLa cells. ${ }^{48}$ These data thus demonstrate the potential of $\mathrm{P}_{\mathrm{N}}$ to inhibit the self-renewal activity of CSCs. The decreased expression of CSC-specific markers endorses cell death in $\mathrm{P}_{\mathrm{N}}$-treated cells and a decrease in the high $\mathrm{CD}_{4} 4^{+}$population would inhibit tumor growth, metastasis and cause relapse. ${ }^{47}$ Phytochemicals capable of altering the expression of both $\mathrm{CD} 44^{+}$and $\mathrm{CD} 24^{+}$have been identified as anti-metastatic agents. ${ }^{49}$ We further explored the possible effects of $\mathrm{P}_{\mathrm{N}}$ exposure on the cytotoxicity, morphology, and expression levels of surface markers among the CSC population by analysing the changes in the $\mathrm{CD} 24^{+}$and $\mathrm{CD} 44^{+}$ expression levels. Our previous findings clearly revealed that in parent HeLa cells, ${ }^{16} \mathrm{P}_{\mathrm{N}}$ was found to be very promotive towards modulating the cellular integrity and mitochondrial membrane potential, DNA fragmentation and ROS production. A reduction in the cytotoxicity, ROS production and apoptotic cell population by $\mathrm{P}_{\mathrm{N}}$ in cells pre-treated with NAC, a ROS scavenger, further confirmed that generation of ROS is the key mechanism by which $\mathrm{P}_{\mathrm{N}}$ inhibits cell proliferation and induces cell death in CSCs. In the present study, the results show enhanced production of ROS, DNA fragmentation, and depolarized mitochondrial membrane potential in the $\mathrm{P}_{\mathrm{N}}$-treated CSCs, which could lead them to cell death through an apoptotic pathway.

\section{Conclusions}

Overall, through the generation of in vitro CSC cultures from HeLa cancer cells, we demonstrated that $\mathrm{P}_{\mathrm{N}}$ has the ability to inhibit CSC proliferation and spheroid formation, ultimately leading the CSCs to apoptotic cell death. These data clearly demonstrate that treatment with plant derived flavonoids such as $\mathrm{P}_{\mathrm{N}}$, which targets both cancer cells ${ }^{\mathbf{1 6}}$ and cancer stem cells (present study), is likely to prove a promising therapeutic strategy, by reducing relapse and recurrence. The individual and combined effects of chemotherapies and flavonoids have been tested in various cancers. The anti-CSC activity of a combination of sulforaphane and dietary-derived flavonoid quercetin has been examined in MIA-PaCa2 pancreatic cancer cells (high proportion of CSCs) using a xenograft model. Although both of these agents individually inhibited the growth of tumors, the combination led to complete eradication. ${ }^{47}$ Similarly, $\mathrm{P}_{\mathrm{N}}$ or other such compounds could possibly be used in combination with existing therapies for improved outcome.

In our study, the mechanism of $\mathrm{P}_{\mathrm{N}}$-induced cell death is probably associated with an increase in ROS generation and depolarization of the mitochondrial membrane potential in CSCs, which leads to downregulation of expressions of stem cell markers and regeneration capacity. However, further studies using in vivo models would confirm the potential of $\mathrm{P}_{\mathrm{N}}$ for cancer treatment, either alone or in combination with existing therapies.

\section{Conflicts of interest}

The authors declare that no conflicting interests exist.

\section{Abbreviation}

BSA Bovine serum albumin

CSCs Cancer stem-like cells

DMEM Dulbecco's modified Eagle's medium

EDTA Ethylenediaminetetraacetic acid

FACS Fluorescence-activated cell sorting

FBS Fetal bovine serum

MMP Mitochondrial membrane potential

MTT 3-(4,5-Dimethylthiazol-2-yl)-2,5-diphenyltetrazolium bromide

PBS Phosphate buffer saline

$\mathrm{P}_{\mathrm{N}} \quad$ Pinostrobin

ROS Reactive oxygen species

SP Side population

\section{Acknowledgements}

The authors are thankful for the financial support from the Department of Biotechnology, New Delhi, India, for the DBTBUILDER grant (BT/PR5006/INF/22/153/2012) and the PURSE grant from the Department of Science and Technology [SR/ PURSE/Phase2/11(C) 2015], New Delhi, India to the Jawaharlal Nehru University, New Delhi, India. The University Grant Commission (UGC) is acknowledged for providing a research fellowship to AJ and SS, respectively. The Advanced Instrumentation Research Facility (AIRF), Jawaharlal Nehru University, New Delhi is acknowledged for providing the FACS and confocal microscopy facilities.

\section{References}

1 A. Sreedevi, R. Javed and A. Dinesh, Int. J. Women's Health, 2015, 7, 405-414.

2 I. Dagogo-Jack and A. T. Shaw, Nat. Rev. Clin. Oncol., 2018, 15, 81-94. 
3 B. Bao, A. Ahmad, A. S. Azmi, S. Ali and F. H. Sarkar, Curr. Protoc. Pharmacol., 2013, 61, 14.25.1-14.25.14.

4 G. Lee, R. R. Hall 3rd and A. U. Ahmed, J. Stem Cell Res. Ther., 2016, 6(10), 363.

5 J. C. Chang, Medicine, 2016, 95, S20-S25.

6 K. Chen, Y. H. Huang and J. L. Chen, Acta Pharmacol. Sin., 2013, 34, 732-740.

7 A. Flemming, Nat. Rev. Drug Discovery, 2015, 14, 165.

8 Z. A. Rasheed and W. Matsui, J. Gastroenterol. Hepatol., 2012, 27(suppl. 2), 15-18.

9 T. Wang, S. Shigdar, M. P. Gantier, Y. Hou, L. Wang, Y. Li, H. A. Shamaileh, W. Yin, S. F. Zhou, X. Zhao and W. Duan, Oncotarget, 2015, 6, 44191-44206.

10 N. Y. Frank, T. Schatton and M. H. Frank, J. Clin. Invest., 2010, 120, 41-50.

11 J. A. McCubrey, K. Lertpiriyapong, L. S. Steelman, S. L. Abrams, L. V. Yang, R. M. Murata, P. L. Rosalen, A. Scalisi, L. M. Neri, L. Cocco, S. Ratti, A. M. Martelli, P. Laidler, J. Dulinska-Litewka, D. Rakus, A. Gizak, P. Lombardi, F. Nicoletti, S. Candido, M. Libra, G. Montalto and M. Cervello, Aging, 2017, 9, 1477-1536.

12 G. M. Cragg and J. M. Pezzuto, Med. Princ. Pract., 2016, 25(suppl. 2), 41-59.

13 H. D. Smolarz, E. Mendyk, A. Bogucka-Kocka and J. Kocki, Z. Naturforsch., C: J. Biosci., 2006, 61, 64-68.

14 Sukardiman, A. Darwanto, M. Tanjung and M. O. Darmadi, Clin. Hemorheol. Microcirc., 2000, 23, 185-190.

15 J. C. Le Bail, L. Aubourg and G. Habrioux, Cancer Lett., 2000, 156, 37-44.

16 A. Jaudan, S. Sharma, S. N. A. Malek and A. Dixit, PLoS One, 2018, 13, e0191523.

17 A. Jadaun, N. Subbarao and A. Dixit, J. Photochem. Photobiol., $B, 2017,167,299-308$.

18 J. W. Fahey and K. K. Stephenson, J. Agric. Food Chem., 2002, 50, 7472-7476.

19 W. Gu, E. Yeo, N. McMillan and C. Yu, Cancer Gene Ther., 2011, 18, 897-905.

20 S. Atashpour, S. Fouladdel, T. K. Movahhed, E. Barzegar, M. H. Ghahremani, S. N. Ostad and E. Azizi, Iran. J. Basic Med. Sci., 2015, 18, 635-643.

21 A. Pouyafar, M. Z. Heydarabad, S. B. Aghdam, M. Khaksar, A. Azimi, R. Rahbarghazi and M. Talebi, 2019, DOI: 10.1002/jcb.28129, Epub ahead of print.

22 J. López, A. Poitevin, V. Mendoza-Martinez, C. PerezPlasencia and A. Garcia-Carranca, BMC Cancer, 2012, 12, 48.

23 M. A. Goodell, K. Brose, G. Paradis, A. S. Conner and R. C. Mulligan, J. Exp. Med., 1996, 183, 1797-1806.

24 M. Bhardwaj, N. H. Kim, S. Paul, R. Jakhar, J. Han and S. C. Kang, PLoS One, 2016, 26, e0154525, DOI: 10.1371/ journal.pone.0154525.

25 L. U. Ling, K. B. Tan, H. Lin and G. N. Chiu, Cell Death Dis., 2011, 2, e129.

26 E. C. Dietze, L. E. Caldwell, S. L. Grupin, M. Mancini and V. L. Seewaldt, J. Biol. Chem., 2001, 276, 5384-5394.
27 C. Bucana, I. Saiki and R. Nayar, J. Histochem. Cytochem., 1986, 34, 1109-1115.

28 S. S. Fard, M. Jeddi-Tehrani, M. M. Akhondi, M. Hashemi and A. M. Ardekani, Avicenna J. Med. Biotechnol., 2010, 2, 53-61.

29 T. Wang, R. Narayanaswamy, H. Ren and V. P. Torchilin, Cancer Biol. Ther., 2016, 17, 698-707.

30 S. Khan, A. Karmokar, L. Howells, A. L. Thomas, R. Bayliss, A. Gescher and K. Brown, Mol. Nutr. Food Res., 2016, 60, 1295-1309.

31 P. B. Gupta, T. T. Onder, G. Jiang, K. Tao, C. Kuperwasser, R. A. Weinberg and E. S. Lander, Cell, 2009, 138, 645-659.

32 M. Ahmed, K. Chaudhari, R. Babaei-Jadidi, L. V. Dekker and A. Shams Nateri, Stem Cells, 2017, 35, 839-850.

33 S. S. Chung and J. V. Vadgama, Anticancer Res., 2015, 35, 3946.

34 R. S. Tarapore, I. A. Siddiqui and H. Mukhtar, Carcinogenesis, 2012, 33, 483-491.

35 S. F. Chen, S. Nieh, S. W. Jao, C. L. Liu, C. H. Wu, Y. C. Chang, C. Y. Yang and Y. S. Lin, PLoS One, 2012, 7, e49275.

36 P. R. Pandey, H. Okuda, M. Watabe, S. K. Pai, W. Liu, A. Kobayashi, F. Xing, K. Fukuda, S. Hirota, T. Sugai, G. Wakabayashi, K. Koeda, M. Kashiwaba, K. Suzuki, T. Chiba, M. Endo, T. Fujioka, S. Tanji, Y. Y. Mo, D. Cao, A. C. Wilber and K. Watabe, Breast Cancer Res. Treat., 2011, 130, 387-398.

37 A. A. Gokbulut, E. Apohan and Y. Baran, Hematology, 2013, 18, 144-150.

38 A. Del Follo-Martinez, N. Banerjee, X. Li, S. Safe and S. Mertens-Talcott, Nutr. Cancer, 2013, 65, 494-504.

39 S. Orrenius, M. Ankarcrona and P. Nicotera, Adv. Neurol., 1996, 71, 137-149; discussion 149-151.

40 S. Jiang, S. C. Chow, P. Nicotera and S. Orrenius, Exp. Cell Res., 1994, 212, 84-92.

41 D. L. Holliday and V. Speirs, Breast Cancer Res., 2011, 13, 215. 42 F. S. Dela Cruz, Front. Oncol., 2013, 3, 168.

43 E. Sugihara and H. Saya, Int. J. Cancer, 2013, 132, 1249-1259.

44 W. Zhao, Y. Li and X. Zhang, Cancer Transl. Med., 2017, 3, 8795.

45 S. N. Tang, C. Singh, D. Nall, D. Meeker, S. Shankar and R. K. Srivastava, J. Mol. Signaling, 2010, 5, 14.

46 J. Manuel Iglesias, I. Beloqui, F. Garcia-Garcia, O. Leis, A. Vazquez-Martin, A. Eguiara, S. Cufi, A. Pavon, J. A. Menendez, J. Dopazo and A. G. Martin, PLoS One, 2013, 8, e77281.

47 A. Z. Ayob and T. S. Ramasamy, J. Biomed. Sci., 2018, 25, 20. 48 D. Wang, B. Upadhyaya, Y. Liu, D. Knudsen and M. Dey, BMC Cancer, 2014, 14, 591.

49 P. R. Dandawate, D. Subramaniam, R. A. Jensen and S. Anant, Semin. Cancer Biol., 2016, 40-41, 192-208.

50 M. Appari, K. R. Babu, A. Kaczorowski, W. Gross and I. Herr, Int. J. Oncol., 2014, 45, 1391-1400. 